\title{
Critical Success Factors Enterprise Resource Planning (ERP) Implementation in Higher Education
}

\author{
Adjeng Kartika Rizkiana \\ Faculty of Economics and Business \\ Universitas Padjadjaran \\ Hamzah Ritchi \\ Faculty of Economics and Business \\ Universitas Padjadjaran \\ Zaldy Adrianto \\ Faculty of Economics and Business \\ Universitas Padjadjaran
}

\begin{abstract}
One of the technologies that can optimise the data management system in Higher Education is the Enterprise Resource Planning (ERP) information system. However, in its implementation, failures often occur. The purpose of this study is to determine and formulate the factors that can be the key to the successful implementation of an ERP system in universities, including state universities and private universities. In this research, a case study was conducted at Padjadjaran University, Bandung Institute of Technology, Prasetya Mulya, and Maranatha University. The research method used is descriptive qualitative through case studies on four campuses mentioned. The 20 critical factors taken to result from iterations of 32 works from 2016-2019 timeframe. The study results provide an overview of the critical success factors that have emerged at each college and university.
\end{abstract}

Keywords: Critical success factors; Enterprise resource planning (ERP); Oracle, SAP, Higher education.

\section{Introduction}

In the current era of competition, building higher education governance is very important. The data management system needs to be improved to create transparent and accountable higher education institutions. By implementing good governance, a university will get the maximum accreditation predicate. One of the aspects being assessed is academic administration, staffing, finance, and higher education households.

The use of information systems based on Enterprise Resource Planning (ERP) technology has been widely used. One of the state universities which already implemented an ERP system was Padjadjaran University. At that time, Unpad Rector Prof. Tri Hanggono Achmad said that ERP implementation in the business sector is a follow-up to the e-office system that has been introduced in Unpad since 2016. This system makes office administration activities efficient and reduces paper for correspondence (Maulana, 2018). In addition to public universities, there are also private universities that have implemented an ERP system, namely Maranatha Christian University, by choosing SAP R/3. This software is expected to help the university improve human resources, business administration, and procurement functions to increase efficiency and effectiveness in terms of cost and time.

From a university perspective, ERP refers to the use of commercial solutions for administrative and academic purposes. Among the main reasons, universities adopt ERP 
solutions are to improve student services, a transformation of corporate processes, modern computer systems, improved administration, maintaining competitiveness and increased operating efficiency (Kumar \& Maheshwari, 2003). However, the cost of implementing an ERP system can even be a costly and high risk of failure outweighed by the costs. From several difficulties in implementing ERP systems in the college/university sector, it became an issue related to Critical Success Factors (CSF) related to communication, business process re-engineering, vendor support, project management, and costs that are not within the budget. The following are three scenarios that could lead to ERP project failure, as mentioned in Willcocks \& Sykes (2000):

Table 1. ERP Trade-Off

\begin{tabular}{lll}
\hline Condition & Focus on Information System & Impact \\
\hline Technology determinism & Rigid budget & Business profit not achieved \\
\hline Vendor domination & Unfocus & Over budget \\
\hline Incompatible relationship & Less competencies & Chaos \\
\hline
\end{tabular}

One studies at universities in Egypt showed that the ERP failure rate in higher education in Egypt is relatively high due to their complex culture. Egyptian culture believes that personal information is something that cannot be shared with others. It causes obstacles for users to implement ERP Matyokurehwa \& Jokonya (2018). Research conducted by Fadelelmoula (2018) at the University of Saudi Arabia conducted a case study at Prince Sattam bin Abdulaziz University, Alkhraj. The research focuses on six CSFs: top management support, training, project management, technical resources, business process re-engineering, and consultant support. The results show that the six CSFs have a positive relationship with the comprehensive achievement of the vital role of CBIS (Computer-Based Information Systems). These findings are consistent with many previous studies on CSF's effect on realising corporate systems' expected benefits.

In this study, the researcher expanded from previous research conducted by Rimayanti (2017), by increasing the period for selecting scientific publications from 2016 to 2019. Also, most of the previous research samples were taken in the industrial sector, while in this study, the sample taken was the education sector, such as universities. By looking at the phenomena previously described, the author considers it necessary to research what factors can support the successful implementation of an ERP system, especially in the higher education sector, both public and private universities in Indonesia that have adopted the ERP system. Factual conditions show that there are already several higher education institutions that have implemented an ERP system.

\section{Literature Review}

Enterprise Resource Planning System (ERP System)

Enterprise Resource Planning (ERP) systems are one of the most popular information technology (IT) software adopted in organisations globally; ERP systems provide solutions for improving the company's operational performance. The increasing use of systems in organisations has resulted in several studies investigating their implementation (Ifinedo, 2006). 


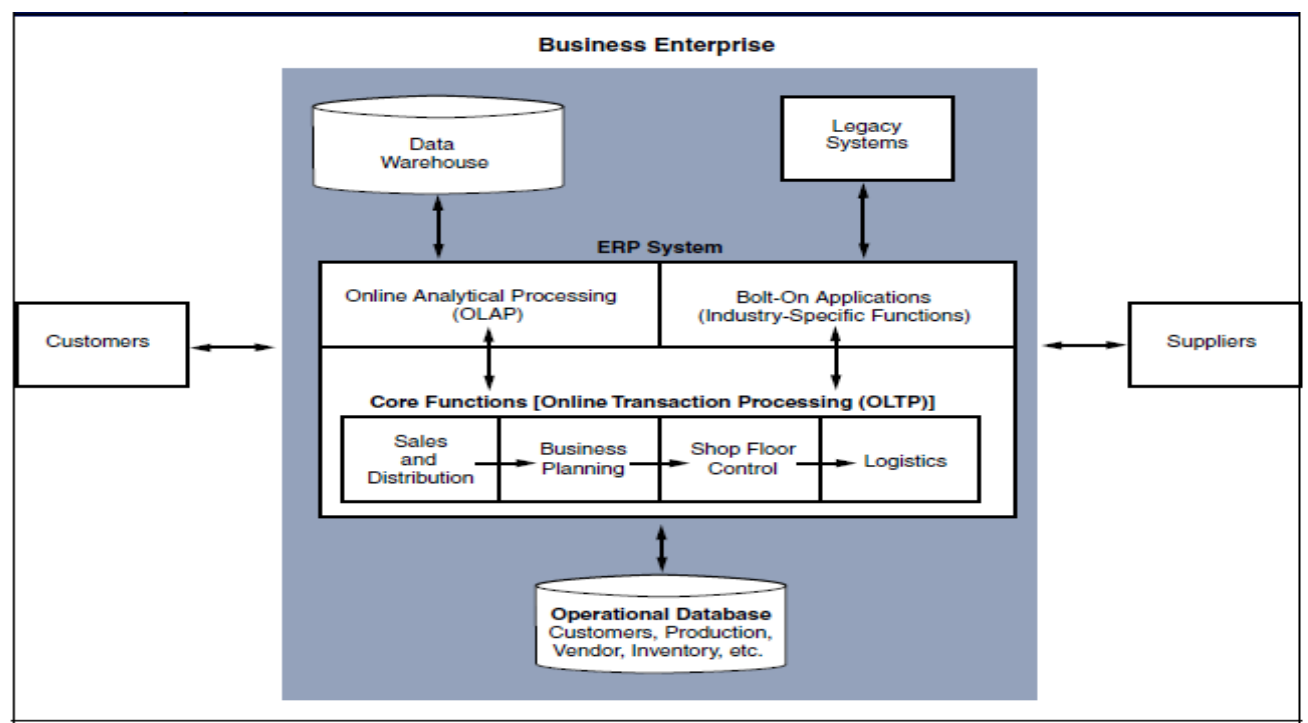

Figure 1. ERP System, Source: (Hall, 2011)

ERP systems integrate information and information-based processes on a part or between parts of an organisation or company. ERP system is a system that can accommodate various functions and integrate them into one integrated database. For example, functions such as Human Resources, Supply Chain Management, Customer Relations Management, Finance, Manufacturing functions and Warehouse Management functions were once standalone software applications, usually located in databases and networks themselves. The ERP system becomes a solution to adjust everything under one application called the ERP system. From this, it can be said that the definition of ERP is more than just software. ERP is a new automated software package solution that effectively integrates, manages, and controls almost all aspects of business processes, functions, and resources across a wide range of business areas using a centralised database, ensuring that all information is entered only once real-time conditions. Further (Rico, 2006) defines ERP systems in a university context, namely information technology solutions that integrate and automate recruitment, acceptance, financial aid, student records, and most academic and administrative services. According to some estimates, 7.5 out of 10 or $75 \%$ of ERP projects fail, leading to much further research.

\section{Critical Success Factors of ERP System Implementation}

Critical success factors (CSF) are an essential part of implementing an ERP system. Frimpon (2012) states that CSF is a critical factor for project success. Based on these experts' descriptions, the author defined CSF as the main criterion in realising the successful implementation of information systems, especially ERP systems. Several studies on the factors that determine the success of ERP system implementation have been done extensively. In 2001 Somers \& Nelson identified 22 factors studied from 86 companies that have implemented ERP systems, some which were analysed based on mean rankings. The study was used as a reference by Akkermans \& Van Helden (2002) who conducted a case study on three aviation companies by taking the top 10 determining factors in Somers \& Nelson (2001), the results showed that these ten factors proved relevant to the failure or success of ERP system implementation in companies (Somers \& Klara, 2001). Hasibuan \& Dantes (2012) surveyed 74 companies that have implemented ERP system in Indonesia, where the determinants of success (CSF) are classified into five categories based on stages in the ERP implementation cycle, namely: project preparation, technology selection, project 
formulation, implementation/development (Hasibuan \& Dantes, 2012). From the results of the study, it is known as CSF is communication, package selection, and change management. Rimayanti (2017) conducted qualitative descriptive research with case study approach in four companies in Indonesia. Twenty-five factors determine the success tested in this study as a result of iteration of 65 literature published in 1998-2015, namely project management, project teamwork and composition, communication, user involvement, user training and education, vendor support, degree of customisation, key user satisfaction, the suitability of hardware, software, data accuracy, easy to use, top management support, project champion, monitoring and evaluation of performance, change management, organisational fit, assets, package selection, organisational readiness, the balance of centrifugal and centripetal forces, business process re-engineering, business plan and vision business process improvement, business process management, cost/budget issues, and culture. This study focus on the higher education sector based on Rimayanti (2017), expanded the range of literature from 2016 to 2019.

\section{DeLone and McLean (D\&M) models}

In the model proposed by William H. DeLone and Ephraim R. McLean (1992), it is stated that six dimensions influence the success of an information system. The six variables are system quality, information quality, service quality, intention to use, user satisfaction, and net benefits. Graphickly, DeLone and McLean (D\&M) model depicted as stated in figure 2.

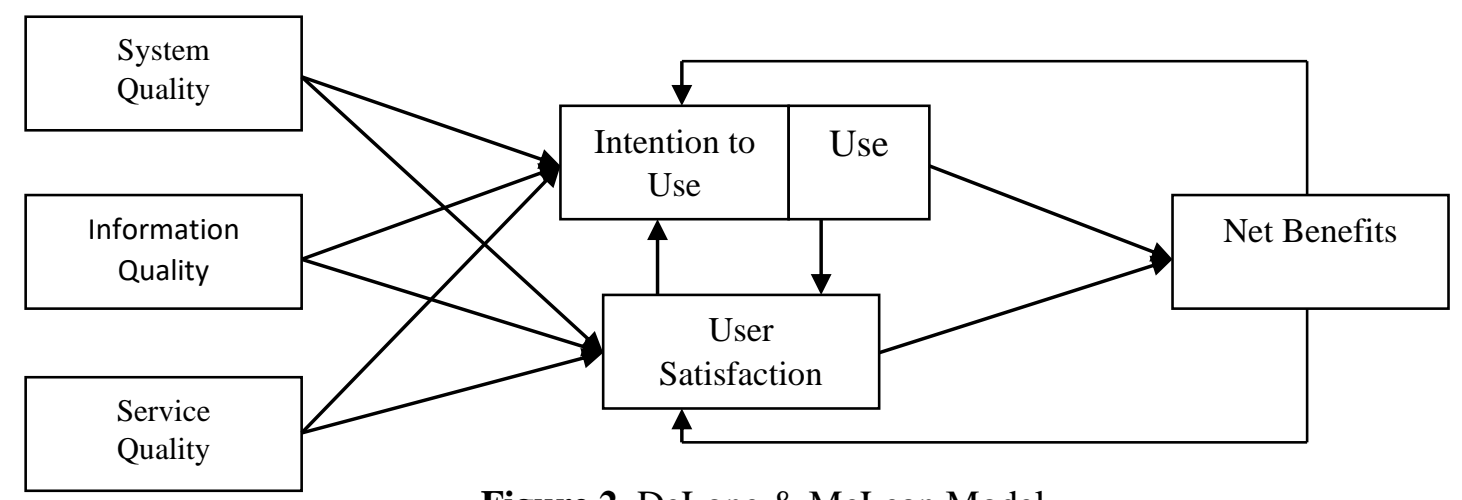

Figure 2. DeLone \& McLean Model

\section{Task Technology Fit Model}

Task Technology Fit (TTF) describes the extent of the match between the facilities provided by the ERP package, the tasks performed by users of that package, and each user's skills and attitudes. Goodhue (1995) has shown that user evaluation of TTF is an accurate representation of TTF. Goodhue and Thompson show that TTF is a useful indicator for the successful implementation of information systems. The perceived usefulness or "aggregate organisational benefits" (Ives and Olson, 1984), is another indicator of success accepted from the theory of information systems implementation. DeLone and McLean (1992) reported user satisfaction as the next important indicator of successful implementation of information systems. In the TTF Model, perceived benefits and user satisfaction are shown as the three constructs that best indicate ERP success in an organisation. In the proposed ERP Success Model, perceived benefits and user satisfaction are shown as the three constructs that most satisfactorily indicate ERP success in an organisation (Smyth,2001) 


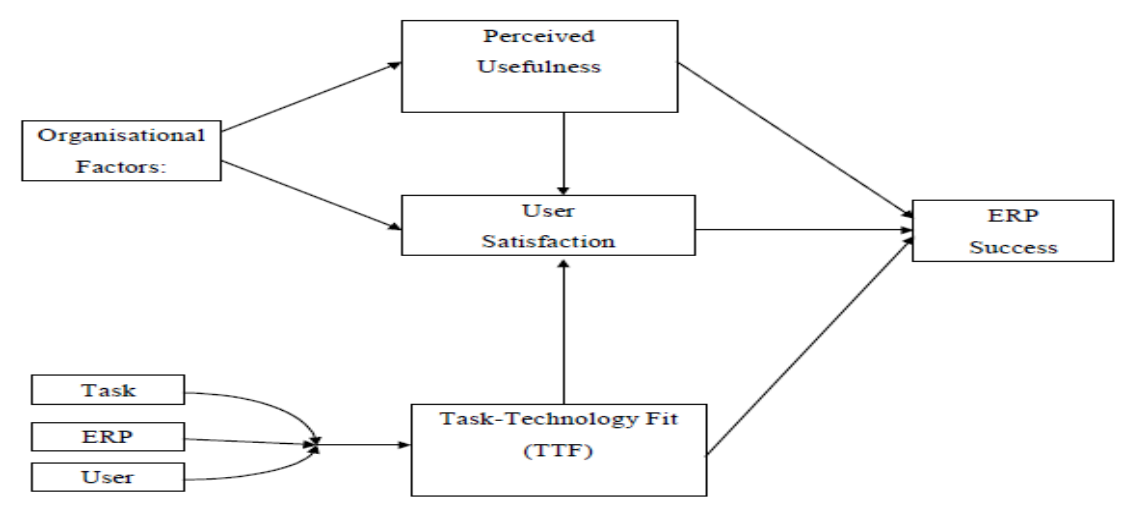

Figure 3. Task Technology Fit ERP Model

\section{Technology Affordance}

The concept of Technology Affordance refers to the potential for action, namely what an individual or organisation can do with a specific purpose through the use of technology or information systems (Majchrzak, Markus: 2012). There is a difference between affordances and afforded, where affordances refer to the potential actions that represent technology for users with specific characteristics and goals, while afforded is used when making uses for specific purposes in certain contexts (Majchrzak, Markus: 2012).

The idea of affordances is used to analyse technology, where the benefits of technology offered must explore the psychological claims inherent in design artefacts and reasons. More generally, considering explicit usability in a design can help to increase the usability of new artefacts. (Gaver, 1991). Concerning technology, the concept of Technology Affordance refers to the potential for action, namely, what an individual or organisation can do with specific goals through the use of technology or information systems (Majchrzak, Markus: 2012). Perception of affordance refers to design choices that serve as more precise communication between technology designers and users. When users interact with technology, they can pick up on a signal that implies or invites specific ways to interact with objects. The three dimensions of technology affordances, namely the dimensions of material, individual, and social aspects, can be used as references for any technology case. Here are some descriptions of the Technology Affordance concept from several researchers.

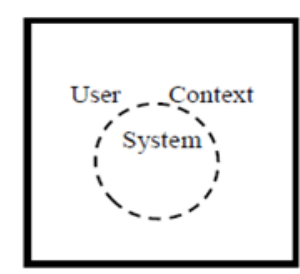

Treem and Leonardi (in press)

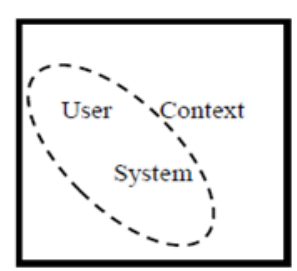

Gaver (1991) Norman (1999) Markus \& Silver (2008)

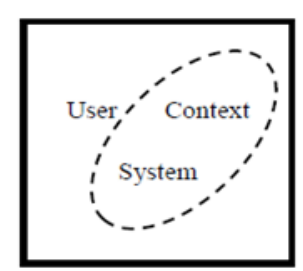

Fayard \& Weeks (2007)

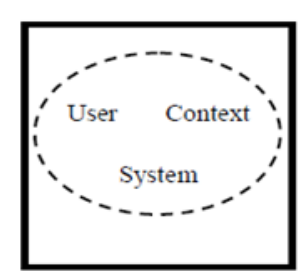

Hutchby (2001) Leonardi (2011)

Figure 4. Technology Affordance Conceptualizations 


\section{Iteration of CSF}

In this study, the literature review was carried out at three stages of iteration described in 6 structured steps. The stages are 1) Identification of 25 CSFs from Rimayanti's (2017) study of reference ranges for 20112015 , 2) Expansion of the timeframe for searching scientific publications on CSF ERP from 2016-2019, 3) Selection of 20 CSF with the highest frequency. After getting the selected journal, make a list of CSFs mentioned in each scientific publication and count the frequencies. Similarities, meaning or concept classified in one CSF category

Twenty CSFs was analysed for later verification at the University/College level.
They were grouped into 4 cluster clusters, namely operational specific (a process or activity carried out from day to day involving human resources), management-specific (managerial has a function to control, supervise, and support the decision-making process for every activity carried out in an enterprise system implementation project), specific strategic issues (strategic benefits are activities with a higher level in decision making, and can determine the direction of the company and enterprise system implementation project in the long term), and local sociocultural specific (linkage to social and cultural conditions or conditions in a country where the enterprise system is applied).

Table 1. Critical Success Factors ERP Implementation

\begin{tabular}{|c|c|}
\hline Dimension & Indicator \\
\hline \multirow{10}{*}{ 1. Operational Specific } & 1. Project management \\
\hline & 2.Project teamwork \& composition \\
\hline & 3.Comunication \\
\hline & 4.User involvement \\
\hline & 5.Training \& Education \\
\hline & 6.Vendor support \\
\hline & 7.Suitability of hardware, software \\
\hline & 8.User acceptance \\
\hline & 9. Data analysis \\
\hline & 10. Degree of customisation \\
\hline \multirow{6}{*}{ 2. Management Specific } & 1. Top management support \\
\hline & 2. Project champion \\
\hline & 3. Monitoring \& evaluation of performance \\
\hline & 4. Change Management \\
\hline & 5. Organizational Fit \\
\hline & 6. Package selection \\
\hline \multirow{3}{*}{ 3. Strategic issues specific } & 1. Business process re-engineering \\
\hline & 2. Business plan \& vision \\
\hline & 3. Cost/budget issues \\
\hline 4. Local \& sociocultural specific & 1. Organisational cultural \& readiness \\
\hline
\end{tabular}


Based on the iterations carried out, the framework in this study which are the keys to successful ERP implementation are as follows:

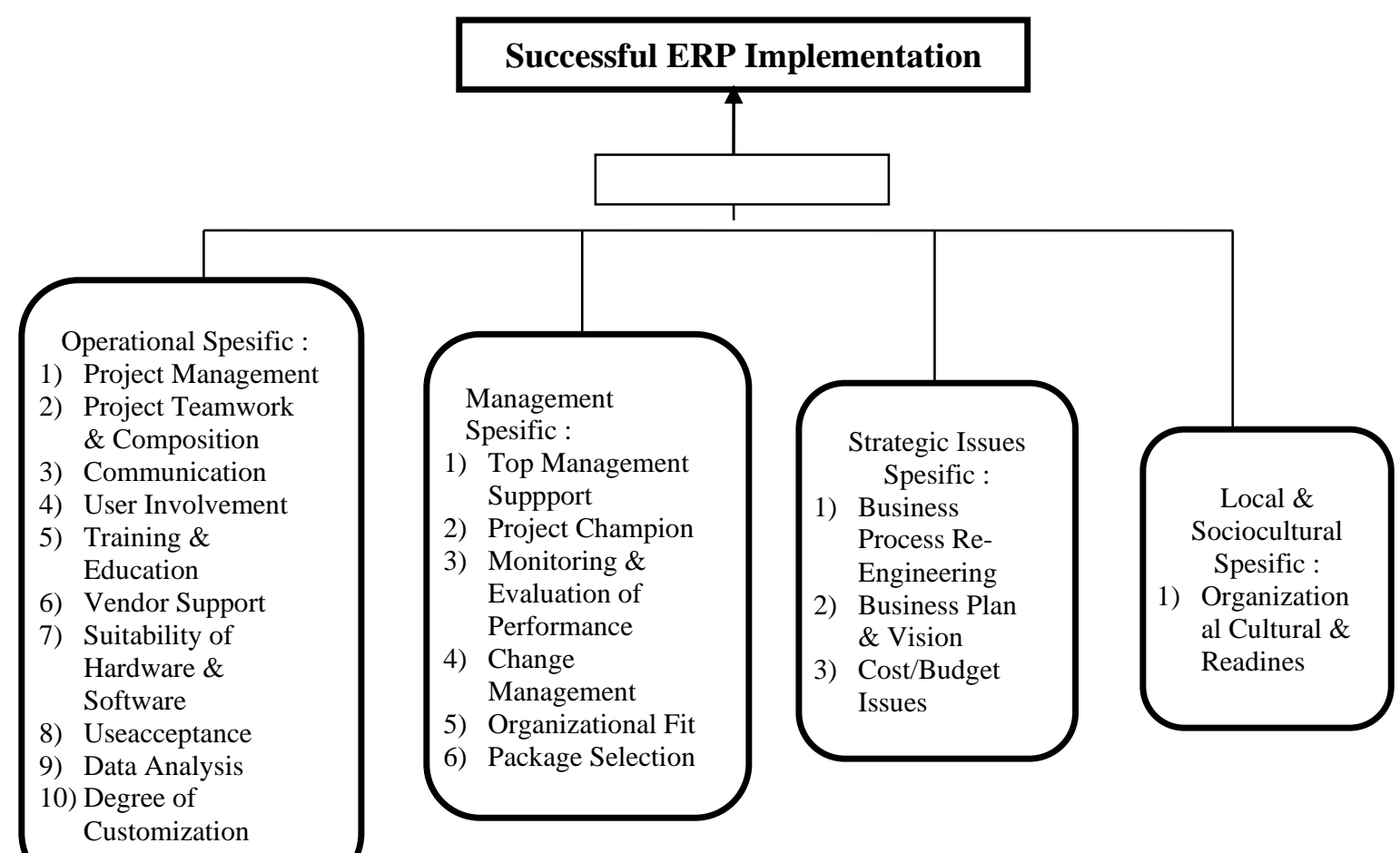

Figure 5. Successful ERP System Implementation

\section{Methods, Data, and Analysis}

This study used a qualitative research method with a case study approach. Sugiyono (2010) adds that the qualitative method is a naturalistic research method with the researcher as the critical instrument using a triangulation (combined) data collection technique. The results of the research provide a deeper meaning than generalisation or what is called inductive analysis. This type of research is descriptive research, which is a writing that describes the actual situation of the object under study, according to the actual situation at the time of direct research. Sample are four colleges in West Java, and they are Bandung Institute of Technology (ITB), Padjadjaran University (Unpad), Maranatha Christian University (Maranatha) and Prasetiya Mulya University (UPM). These campuses selected using purposive sampling, which universities have implemented ERP systems in Global System ERP Applications, such as Oracle, Epicor, Microsoft Dynamic, and SAP. Interviews were conducted at work units involved in implementing the ERP system used. Data analysis in qualitative research is carried out during data collection and after completing data collection within a certain period. At the time of the interview, the researcher had analysed the informant's answers. If the informant's answer after being analysed is deemed unsatisfactory, the researcher will continue the question until the data obtained was considered credible... Miles and Huberman (1984), suggest that activities in qualitative data analysis are carried out interactively and continue continuously until completion so that the data is saturated.

\section{Result and discussion}

Summary of Key Factors for Successful ERP System Implementation

Referring to the social situation of higher education institutions that implement Oracle and SAP ERP systems, it can be seen that the factors studied show variations in appearance 
in practice. The following summarises the critical factors for successfully implementing the Oracle and SAP ERP systems in four sample universities.

Table 2. Critical Factors for Successful ERP System Implementation

\begin{tabular}{|c|c|c|c|c|c|}
\hline No. & CSF & ITB & Unpad & Maranatha & UPM \\
\hline & Operational Specific & & & & \\
\hline 1. & Project Management & & & & \\
\hline 2. & Project teamwork \& composition & & & & \\
\hline 3. & Communication & & & & \\
\hline 4. & User involvement & & & & \\
\hline 5. & Training \& Education & & & & \\
\hline 6. & Vendor Support & & & & \\
\hline 7. & Suitability of hardware $\&$ software & & & & \\
\hline 8. & User acceptance & & & & \\
\hline 9. & Data Analysis & & & & \\
\hline \multirow[t]{2}{*}{10.} & Degree of customisation & & & & \\
\hline & Management Specific & & & & \\
\hline 1. & Top Management Support & & & & \\
\hline 2. & Project champion & & & & \\
\hline 3. & Monitoring \& evaluation of performance & & & & \\
\hline 4. & Change Management & & & & \\
\hline 5. & Organizational Fit & & & & \\
\hline \multirow[t]{2}{*}{6.} & Package Selection & & & & \\
\hline & Strategic Issues Specific & & & & \\
\hline 1. & Bussines process re-engineering & & & & \\
\hline 2. & Bussines Plan \& Vision & $\theta$ & & & \\
\hline \multirow[t]{2}{*}{3.} & Cost/ budget issues & & & & \\
\hline & Local \& sociocultural Specific & & & & \\
\hline 1. & Organizational Culture \& readiness & & & & \\
\hline
\end{tabular}

Symbol Description

$\bigcirc \quad$ : Factors found in social situations

$\bigoplus \quad$ : Few factors are found in social situations

X: Factors not found in social situations 
Based on information stated in Table 2, it can be identified that there are variations in the emergence of crucial success factors in each sample of universities taken. Based on informants' explanations, the researcher described the social situation that could represent whether the factors were believed to be the critical factors for implementing an ERP system at the beginning of the implementation period.

From the table above it can be concluded that the critical success factors most often found are from the Operational Specific dimensions: Project Management, Project Teamwork \& composition, Communication, User involvement, Suitability of hardware \& software, as well as from the dimensions of Local \& Sociocultural Specific: Organizational Culture \& readiness. Thus, it is hoped that these factors will become an essential concern for other campuses that will also start choosing ERP systems at their institutions. However, there is also a factor in the Management Specific, namely the Project Champion, which was not found in the sample of universities implementing ERP systems. It is different from the cost/budget issue factor, which is interpreted as a cross, but it does not mean that this factor is not found in social situations. It means that there is no problem in terms of costs associated with implementing the ERP system.

From several samples of universities studied, it was found that each campus was unique. For example, ITB is a pioneer campus that implements Oracle in the tertiary category so that ITB can get privileges at the license price. However, it is unfortunate because developments in the system were less than optimal compared to other campuses that have just implemented Oracle. On the Unpad campus, it was found that the Oracle used was superior because it was able to connect the payment system with banks, but there were still failures in the Budgeting system. At the Maranatha campus, it has succeeded in implementing SAP with a taxation system (in this case corporate income tax), which can be relied on to be precise, on time, and on principle, even though the implementation of the first year was considered quite difficult. UPM campus has implemented SAP's latest version, although it needed lots of training, some training has even done overseas.

\section{Conclusion}

Bandung Institute of Technology, the results of research at the Bandung Institute of Technology (ITB) found 17 critical factors for the success of implementing an ERP system, namely: Project Management, Project teamwork \& composition, Communication, User involvement, Training \& Education, Vendor support, Suitability of hardware \& software, User acceptance, Data analysis, Degree of Customisation, Top Management Support, Monitoring and Evaluation of Performance, Organizational Fit, Package Selection, the Business process re-engineering, the Business Plan and Vision and Organizational Culture \& readiness.

Padjadjaran University, there are 19 factors critical to the successful implementation of the ERP system at the University of Padjadjaran, namely: Project Management, Project teamwork, and composition, Communication, User involvement, Training \& Education, vendor support, Suitability of hardware \& software, user acceptance, data analysis, Degree of Customisation, Top Management Support, Monitoring \& Evaluation of Performance, Change Management, Organizational Fit, Package Selection, Business process reengineering, Business Plan \& Vision and Organizational Culture \& readiness.

Maranatha Christian University, In research at Maranatha Christian University, there are 7 critical factors for successful implementation, namely: Project Management, Project teamwork \& composition, Communication, User involvement, Training \& Education, Vendor support, Suitability of hardware \& software, User acceptance, Data 
analysis, Degree of Customisation, Top Management Support, Monitoring and Evaluation of Performance, Change Management, Organizational Fit, Package Selection, the Business Plan and Vision and Organizational Culture \& readiness.

Prasetiya Mulya University, 13 critical factors for the success of the ERP system at Prasetiya Mulya University are Project Management, Project teamwork \& composition, Communication, Training \& Education, Vendor support, Suitability of hardware \& software, User acceptance, Top Management Support, Monitoring \& Evaluation of Performance, Change Management, Package Selection, Business Plan \& Vision, and Organizational Culture \& readiness. The limitation of this research lies in access to informants. Future research could focus in a broader area of higher education, more in-depth interviews.

\section{References}

Abugabah, A., Sansogni, L., \& Abdulaziz, O. (2013). The Phenomenon of Enterprise Systems in Higher Education: Insights From Users. International Journal of Advanced Computer Science and Applications, 4(12), 79-85.

Ahmed, N., A., A., \& Sarim, M. (2017). Critical Success Factors Plays a Vital Role in ERP Implementation in Developing Countries: An Exploratory Study in Pakistan. International Journal of Advanced Computer Science and Applications, 8(10), 21-29.

Aladwani, A. M. (2001). Change management strategies for successful ERP implementation. Business Process Management Journal, 7(3), 266-275.

Aldayel, M. S., \& Al-Mudimigh, A. S. (2011). The Critical Success Factors of ERP implementation in Higher Education in Saudi Arabia: A Case Study. Journal of Information Technology and Economic Development, 2(October), 1-16.

Alqashami, A., \& Mohammad, H. (2015). C critical Success Factors For Implementing An ERP System Within University Context : Concepts. 7(4), 1-
19. https://doi.org/10.5121/ijmit.2015.7401

Amberg, P. M., Fischl, F., \& Wiener, M. (2005). Background of critical success Factor Research (Issue 2).

Barth, C., \& Koch, S. (2019). Critical success factors in ERP upgrade projects. Industrial Management and Data Systems, 119(3), 656-675.

Chatzoglou, P., Fragidis, L., Chatzoudes, D., \& Symeonidis, S. (2016). Critical success factors for ERP implementation in SMEs. Proceedings of the 2016 Federated Conference on Computer Science and Information Systems, FedCSIS 2016, 8, 1243-1252.

Esteves, J. M., \& Pastor-Collado, J. A. (2002). Understanding the ERP Project Champion Role and Its Criticality. Ecis, 2002, 1077-1086.

Fadelelmoula, A. A. (2018a). The effects of the critical success factors for ERP implementation on the comprehensive achievement of the crucial roles of information systems in the higher education sector. Interdisciplinary Journal of Information, Knowledge, and Management, 13, 21-44.

Frimpon, M. F. (2012). A Re-Structuring Of The Enterprise Resource Planning Implementation Process. 3(1), 231-243.

Gollner, J. A., \& Baumane-vitolina, I. (2017). Measurement of ERP-project success : Findings from Germany and Austria Measurement of ERP-Project Success : Findings from Germany and Austria. January.

Hall, J. A. (2011). Accounting Information Systems Seventh Edition (7th ed.). SouthWestern Cengage Learning.

Hasibuan, Z. A., \& Dantes, G. R. (2012). Priority of Key Success Factors ( KSFS ) on Enterprise Resource Planning ( ERP ) System Implementation Life Cycle. 2012.

Ifinedo, P. E. (2006). Enterprise Resource Planning Systems Success Assessment : An Integrative Framework Princely Emili Ifinedo Enterprise Resource Planning Systems Success Assessment: An Integrative Framework.

Jacqueline. (n.d.). Contoh Kegagalan Dalam Proyek SAP ERP \& Pelajaran yang Dapat Dipetik.

Kanchana, V., \& Sri Ranjini, S. (2018). Investigation and study of vital factors in 
selection, implementation and satisfaction of ERP in small and medium scale industries.

Kiran, T. S., \& Reddy, A. V. (2019). Critical success factors of ERP implementation in SMEs. Journal of Project Management, 4, 267-280.

Kumar, A., \& Gupta, P. C. (2012). Identification and Analysis of Failure Attributes for an ERP System. Procedia Social and Behavioral Sciences, 65(ICIBSoS), 986-991.

Li, H. J., Chang, S. I., \& Yen, D. C. (2017). Investigating CSFs for the life cycle of ERP system from the perspective of IT governance. Computer Standards and Interfaces, 50(October 2016), 269-279. Matyokurehwa, K., \& Jokonya, O. (2018). Enterprise Resource Planning ( $E$ ERP ) S Systems s in High her Education: A Deeper Lo ook at Their Failures s and the Way Forward. September.

Maulana, A. (2018). Unpad Mulai Terapkan Sistem ERP untuk Transaksi Finansial.

Mesgari, M., \& Faraj, S. (2012). Technology affordances: The case of Wikipedia. 18th Americas Conference on Information Systems 2012, AMCIS 2012, 5, 38333841.

Metrasys. (2018). Universitas Kristen Maranatha Menggunakan SAP untuk Mendukung dan Meningkatkan Manajemen Operasional di Lembaga Universitas.

Mitra, P., \& Mishra, S. (2016). Behavioral Aspects of ERP Implementation : A Conceptual Review Models Explaining Implementation of the ERP System. 11, 17-30.

Monk, E., \& Wagner, B. (2013). Concepts In Enterprise Resource Planning.

Motwani, J., Subramanian, R., \& Gopalakrishna, P. (2005). Critical factors for successful ERP implementation : Exploratory findings from four case studies. Computers in Industry, 56, 529544.

Nandi, M. L., \& Kumar, A. (2016). Centralisation and the success of ERP implementation. Journal of Enterprise Information Management, 29(5), 728750. https://doi.org/10.1108/JEIM-072015-0058
Osman, N., \& Sahraoui, A.-E.-K. (2018). A Software Requirement Engineering Framework to Enhance Critical Success Factors for ERP Implementation. International Journal of Computer Applications, 180(10), 32-37. 0

Petter, S., \& McLean, E. R. (2009). A metaanalytic assessment of the DeLone and McLean IS success model: An examination of IS success at the individual level. Information and Management, 46(3), 159-166.

R.Baskaran, \& Associate. (2018). ISSN: 17480345 (Online) www.tagajournal.com. 14, 2505-2528.

Raafat Saade, \& Nijherhors, H. (2016). Critical success factors in enterprise resource planning implementation: a review of case studies. Journal of Enterprise Information Management, 29(1).

Rabaa', A. A., \& Gable, G. G. (2009). ERP Systems in the Higher Education Sector: A Descriptive Case Study. 20th Australian Conference on Information Systems, December 2009, 456-470.

Rabaa'i, A. A., Bandara, W., \& Gable, G. G. (2009). ERP systems in the higher education sector: A descriptive case study. ACIS 2009 Proceedings - 20th Australasian Conference on Information Systems, 456-470.

Ram, J., Corkindale, D., \& Wu, M. (2013). Implementation of critical success factors ( CSFs ) for ERP : Do they contribute to implementation success and postimplementation performance? Intern. Journal of Production Economics, 144(1), 157-174.

Rasmy, M. ., Tharwat, A., \& Ashraf, S. (2005). Critical Success Factors across Enterprise Resource Planning. 1-13.

Rico, D. F. (2006). ERP in Higher Education ERP in Higher Education.

Rimayanti, T. (2017). Faktor-Faktor Penentu Keberhasilan Penerapan Enterprise System di Indonesia : Universitas Padjajaran.

Seddon, P. B. (1997). A Respecification and Extension of the DeLone and McLean Model of IS Success. In Information Systems Research (Vol. 8, Issue 3, pp. 240-253).

Shatat, A. S., \& Dana, N. (2016). Critical Success Factors across the Stages of ERP 
System Implementation in Sohar University: A Case Study. International Journal of Management and Applied Research, 3(1).

Smyth, R. W. (2001). Challenges to successful ERP use. ECIS 2001 Proceedings, June.

Somers, T., \& Klara, N. (2001). The Impact of Somers, T., \& Klara, N. (2001). The Impact of Critical Success Factors across the Stages of Enterprise Resource Planning Implementations Enterprise Resource Planning Implementations. System Sciences, 2001. System Sciences, 2001. Proceedings of the 34th Hawaii International Conference on System Sciences, OO(c), 1-10.

Sugiyono, P. D. (2016). In Journal of Chemical Information and Modeling (Vol. 53, Issue 9).

Yassien, E., Masa'deh, R., Mufleh, M., Alrowwad, A., \& Masa'deh, R. (2017). The Impact of ERP System's Usability on Enterprise Resource Planning Project Implementation Success via the Mediating Role of User Satisfaction. Journal of Management Research, 9(3), 49. https://doi.org/10.5296/jmr.v9i3.11186

Zhang, L., Lee, M. K. O., Zhang, Z., \& Banerjee, P. (2002). Critical success factors of enterprise resource planning systems implementation success in China: Proceedings of the 36th Hawaii international conference on system sciences. 